\title{
A Comparative Analysis of English Language Teacher Education Programs in Turkey and Malaysia
}

\begin{tabular}{|c|c|}
\hline Ali Kara & Ergül Yavuz ${ }^{2}$ \\
\hline $\begin{array}{l}\text { Type/Tür: } \\
\text { Research/Araştırma } \\
\text { Received/Geliş Tarihi: July } \\
\text { 20/20 Temmuz } 2018 \\
\text { Accepted/Kabul Tarihi: } \\
\text { September 3/3 Eylül } 2018 \\
\text { Page numbers/Sayfa No: 287-306 } \\
\text { Corresponding } \\
\text { Author/Iletişimden Sorumlu } \\
\text { Yazar: } \\
\text { akarakas@mehmetakif.edu.tr } \\
\text { L iThenticate } \\
\text { This paper was checked for } \\
\text { plagiarism using iThenticate } \\
\text { during the preview process and } \\
\text { before publication. / Bu çalışma } \\
\text { ön inceleme sürecinde ve } \\
\text { yayımlanmadan önce iThenticate } \\
\text { yazılımı ile taranmıştır. } \\
\text { Copyright @ 2018 by } \\
\text { Cumhuriyet University, Faculty } \\
\text { of Education. All rights reserved. }\end{array}$ & $\begin{array}{l}\text { Abstract } \\
\text { This paper reports on findings from a comparative study that } \\
\text { attempted to identify the differences and similarities between the } \\
\text { English language teacher education programs employed in Turkey } \\
\text { and Malaysia. Employing a qualitative case study research design, } \\
\text { document analysis was used to compare the programs in terms of } \\
\text { several points. To this end, information related to each program } \\
\text { was gathered from the relevant webpages of the programs and } \\
\text { then subjected to content analysis. The analysis of the data } \\
\text { revealed that the ELTEPs differ from each other in two main } \\
\text { aspects, i.e. course-related and non-course related. In terms of } \\
\text { course-related aspects, the programs vary across course contents, } \\
\text { total credits, types of courses, with the Malaysian ELTEP having } \\
\text { non-secular courses in the curriculum. Concerning non-course- } \\
\text { related issues, it was found that differences lie in the length of the } \\
\text { programs, the school types student-teachers can be appointed to } \\
\text { after graduation, overseas experiences, length of field experience } \\
\text { and career prospects. Finally, drawing on the differences and } \\
\text { similarities between the two programs, suggestions are made to } \\
\text { improve the programs by bearing in mind the strong sides of each } \\
\text { program. } \\
\text { Keywords: English language teacher education, program } \\
\text { evaluation, student-teachers, language teaching in Turkey and } \\
\text { Malaysia. }\end{array}$ \\
\hline
\end{tabular}

\section{Suggested APA Citation/Önerilen APA Atıf Biçimi:}

Karakaş, A., \& Yavuz, E. (2018). A comparative analysis of English language teacher education programs in Turkey and Malaysia. Cumhuriyet International Journal of Education, 7(3), 287-306. http://dx.doi.org/10.30703/cije.446313

\footnotetext{
${ }^{1}$ Dr. Öğr. Üyesi, Mehmet Akif Ersoy Üniversitesi, Eğitim Fakültesi, İngiliz Dili Eğitimi, Burdur/Türkiye Assist. Prof. Dr, Mehmet Akif Ersoy University, Faculty of Education, English Language Teaching, Burdur/Turkey e-mail: akarakas@mehmetakif.edu.tr ORCID ID: https://orcid.org/0000-0002-9790-8562

2 Yüksek Lisans Öğrencisi, Mehmet Akif Ersoy Üniversitesi, Eğitim Bilimleri Enstitüsü, Burdur/Türkiye MA Student, Mehmet Akif Ersoy University, Educational Science Institute, Burdur/Turkey e-mail: ergulyavuz@gmail.com ORCID ID: https:/ / orcid.org/0000-0001-6802-8868
} 


\title{
Türkiye ve Malezya' daki İngilizce Öğretmeni Yetiştirme Programlarının Karşılaştırmalı Bir Analizi
}

\begin{abstract}
Öz
Bu makale, Türkiye ve Malezya'da uygulanan İngilizce Öğretmeni Yetiştirme Programları arasındaki farklılıkları ve benzerlikleri belirlemeye yönelik karşılaştırmalı bir çalışmadan elde edilen bulguları sunmaktadır. Nitel vaka araştırması deseni kullanılarak, programların çeşitli noktalardan karşılaştırılması için belge analizi yöntemi seçilmiştir. Bu amaçla, her programla ilgili bilgiler, programların ilgili web sayfalarından toplanmış ve içerik analizine tabi tutulmuştur. Verilerin analizi, İngilizce Öğretmeni Yetiştirme Programlarının birbirinden, dersle ilgili ve ders dışı ilişskili olmak üzere, iki ana açıdan farklılık gösterdiğini ortaya çıkarmıştır. Ders ile ilgili yönler açısından, programlar ders içeriği, toplam krediler, ders türleri, özellikle Malezya İngilizce Öğretmeni Yetiştirme Programının müfredatında seküler olmayan derslere sahip olması açısından farklılık göstermektedir. Ders dışı konular ile ilgili olarak, farklılıkların programların uzunluğunda, öğretmen adaylarının mezuniyet sonrası çalışabilecekleri okul türlerinde, yurt dışı deneyimlerinde, öğretmenlik uygulamalarında ve kariyer olanaklarında yattı̆̆ı ortaya çıkmıştır. Son olarak, iki program arasındaki farklılıklar ve benzerliklerden yararlanarak, her bir programın güçlü yanlarını dikkate alarak programların iyileştirilmesi için önerilerde bulunulmuştur.
\end{abstract}

Anahtar Kelimeler: İngilizce öğretmeni yetiştirme, program değerlendirme, öğretmen adayları, Türkiye ve Malezya' da dil eğitimi

\section{Introduction}

Recently, the increasing prominence of English has become undeniable. As noted by Karakaş (2012), “[t]he starring role of English in the current globalized world has augmented due to its being an international and well-recognized language across the world" (p.1). Owing to its being the major lingua franca of communication in several domains, the effective teaching of English has become a pivotal issue for countries. Hence, it has become evident to policy-makers and scholars that the way to effective English teaching is through training language teachers efficiently by equipping them with field knowledge, pedagogical knowledge, general world knowledge and field experience (Altunya, 2006; Gebhard, 2009). Considering the claim that people's poor level of English proficiency partly originates from the pitfalls of the English language teacher education programs (ELTEP henceforth), research into teacher education programs is considered to be a fruitful area for researchers (Kic-Drgas \& Çomoğlu, 2017).

It should be noted, though, that as Kildan et al., (2013) maintain, teacher education is a superordinate concept consisting of several components, such as preservice training, in-service training, and field experience. According to Demir (2015), "[o]f these components, pre-service teacher training deserves particular attention due to the fact that it is the first step towards professionalization", and therefore "evaluation is at the heart of pre-service training for further improvement of its quality" (p. 157). Initially dating back to the 1990s when teacher education programs were a relatively less studied area (Day, 1991; Weir \& Roberts, 1994), research attempts to evaluate ELTEPs have intensified in the Turkish context in the past two decades or so. Much of the existing research evaluated the programs from the perspectives of the stakeholders (i.e. teacher trainers, teacher candidates and in- 
service teachers) (e.g., Coşkun \& Daloğlu, 2010; Coşgun-Ogeyik, 2009; Demir, 2015; Erozan, 2005; Karakaş, 2012; Türken, 2017). There is also research that has dealt with comparing language teacher education curricula of ELT departments of different institutions within Turkey (e.g., Aydoğan \& Çilsal, 2007; Sanli, 2009). However, despite this growing body of research, there is little published comparative data (e.g., Coşkun, 2008; Kic-Drgas \& Çomoğlu, 2017) on Turkey's ELTEP and those of other countries. We believe that comparative studies are useful in respect of determining similarities and differences as well as weaknesses and strengths in ELTEPs of different institutions. Another advantage of doing comparative studies is to learn and benefit from good sides of each ELTEP. Such studies are of particular importance given that in Turkey, "the changes are inadequate to meet the needs of the candidate teachers in many aspects, especially compared to the programs employed in the developed countries" (Ulum, 2015, p. 44).

There is, therefore, a need to explore the current ELTEP in Turkey in comparison with other ELTEPs in other countries with similar characteristics. This present study focuses on ELTEPs of two countries, i.e. Turkey and Malaysia, with an eye to comparing and contrasting Malaysian and Turkish ELTEPs to find similarities and differences with respect to course-related (e.g., types of courses and course content) and non-course-related matters (e.g., the model of teacher education). We chose Malaysian ELTEP for a twofold reason. Firstly, it was practical for us to collect as much information as possible about the Malaysian ELTEP as we had some intermediaries there, and secondly Malaysia and Turkey share various similarities in terms of culture, religion, and education. Especially, Malaysian education system has evolved considerably over the recent years among many other Islamic countries. And this makes the comparison of Malaysian ELTEP rather than a European one with the Turkish ELTEP much more intriguing to explore.

\section{Teacher Education: Key Concepts and Building Blocks}

Teacher education refers to "[f]ormal teacher training (pre-service or in-service) designed to equip teachers with the knowledge, attitude, behaviour and skills required for teaching at the relevant level" (Teacher Education-UNESCO UIS, 2018, para. 1). When teacher educators strive to equip student-teachers with the required skills, behaviours and knowledge, they make use of different models of teacher education. Wallace (1991) enumerates these models as follows: craft/apprenticeship model, applied science model, reflective/constructivist models and competencybased (standards-based) models. In the craft/apprenticeship model, student-teachers work with classroom teachers to develop experiential knowledge from the expert teachers' teaching techniques via observation, imitation and practice. However, the applied science model, also known as "the rationalist learn-the-theory-then-apply-itmodel" (Ur, 1992, p. 57), mandates student teachers to learn research-based theories to such a level that they are capable enough to apply learned theories in practice. ELTEPs based on this model consists of "theoretical courses in aspects of linguistics, language-learning theories, psychology, and so on" (Ur, 1992, p. 56). As for the reflective/constructivist model, the assumption is that student teachers can develop professional competence through evaluating and reflecting on and adapting their own practices that are built upon the received knowledge and previous experiential 
knowledge. Finally, competency-based programs single out particular competency areas to be acquired by student-teachers along with parallel assessment criteria for these competencies.

Regardless of which model of teacher education is followed, initial teacher education curricula consist of particular components and sub-components. These components are subject knowledge (personal language skills, knowledge about language and culture knowledge), pedagogical knowledge (lesson planning and delivery, language-teaching methods/techniques, classroom management, language assessment techniques) and contextual knowledge (curriculum, student needs and characteristics, institutions) that largely constitute the content of teacher education (Cross, 1995; Glenfell, Kelly, \& Jones, 2003; Shulman, 1987). Through these components, the aim is to equip student-teachers with content knowledge, general pedagogic knowledge, pedagogic content knowledge and support knowledge (Day, 1991; Glenfell et al., 2003). Also, some scholars suggest that technology related courses be included in ELTEPS (Altan, 2006; Peyton, 1997). However, these components and knowledge areas might be unevenly distributed in ELTEPs depending on the model of teacher education used.

\section{ELTEP Evaluation Research in Turkey}

Research on ELTEP in Turkey has flourished particularly in the last ten years and researchers have explored it from different angles due to the variety of matters they are interested in. It seems that that much research has relied on data obtained from student-teachers' opinions (Coşgun-Öğeyik, 2009; Hişmanoğlu, 2012; İnal and Büyükyavuz, 2013; Seferoğlu, 2006), to a lesser extent, teacher educators' views (e.g., Yavuz and Zehir-Topkaya, 2013), and both student-teachers and teacher educators' (e.g., Coşkun-Daloğlu, 2010; Demir, 2015; Salihoğlu, 2012; Türken, 2017) as well as student-teachers and graduates' (Uzun, 2016) views about the program and its components. Some researchers have included the views of practising teachers in their studies (e.g., Erten, 2015). Non-empirical research was also conducted on the current ELTEP, analysing the overall strengths and weaknesses of the program along with the discussion of potential solutions to the identified weaknesses (Karakaş, 2012; Toköz-Göktepe, 2015; Ulum, 2015).

The studies conducted with student-teachers found that overall, they felt satisfied with the content of the ELTEP in their respective degree programs, yet had some complaints about different aspects of the program. For instance, they expressed discontent with the lack of culture-specific courses (Cosgun-Ogeyik, 2009), the inadequacy of the ELTEP to equip students with critical thinking skills (Hişmanoğlu, 2012), the content of the teaching practice (İnal \& Büyükyavuz, 2013), the incapacity of the program to meet students' needs and its being non-operational (Demir, 2015) and the lack of opportunities for micro teaching (Seferoğlu, 2006).

Similarly, those studies disclosing the views of both teacher educators and student-teachers, as well as practising teachers observed a great deal of satisfaction with the current ELTEP and its curricula among the participants. However, serious concerns were raised by teacher educators in relation to different characteristics of the ELTEP, such as the effectiveness of the ELTEP in preparing student-teachers for real-life language teaching (Demir, 2015), the improper arrangement of courses and 
the lack of clarity in some course content (Yavuz \& Zehir-Topkaya, 2013), and the failure of the ELTEP to equip student-teachers with the desired level of linguistic competence (Coşkun-Daloğlu, 2010). Additionally, teacher educators had complaints about the ambiguity in the objectives of the ELTEP and what educational philosophy lies behind it (Salihoğlu, 2012). Unlike these macro-level issues, at a micro level, researchers found that not only student-teachers but also teacher educators believe that pedagogical and technical courses in the ELTEP curricula do not contribute to the development of student-teachers' ICT knowledge and skills, to a satisfactory extent (Uzun, 2016). Finally, a recent study by Erten (2015) with practising teachers indicated that in-service teachers did not feel satisfied with the ELTEP program in terms of its effectiveness in preparing them for actual classroom teaching.

Largely echoing the findings of the above studies, critical reviews of the ELTEP demonstrated that the current (i.e. the 2006) ELTEP became stronger in many respects, such as the addition of some mandatory courses, i.e. Community Service, Listening and Pronunciation and Additional Foreign Language, the addition of a pedagogic dimension to literature courses, and the increased cooperation between teacher educators and mentors at schools, and the offer of mandatory technologyrelated courses (Toköz-Göktepe, 2015; Karakaş, 2012). However, as for the weaknesses observed in the ELTEP, it emerged that the grave problems respectively arise from the insufficient space allocated to teaching practice and microteaching, the failure to meet students' current needs, the negligence of linguistic competence in favour of pedagogical competence and the lack of a reflective thinking component. Karakaş (2012) particularly takes issue with the applied science model the program is based on, and argues for the integration of theory and practice in the program, starting from the onset of teacher education.

Another study that is particularly pertinent to the current study is that of KicDrgas and Çomoğlu (2017) who analysed the Turkish and Polish ELTEPs. Their analysis showed that there are profound differences between the ELTEPs of the two countries concerning the length of education, the school types graduates can work after graduation, and the teaching practice in different types of schools. For example, the length of teacher education is three years in Poland, yet (at least) four years in Turkey. In Poland, BA graduates can work at primary schools and lower high schools. In contrast, in Turkey, graduates can work in public schools of any level upon successfully passing the Civil Servant Selection Exam (known as KPSS). In Poland, graduates need to have an MA degree to be able to teach in all types of schools, though. While Polish student-teachers are obliged to fulfil compulsory practice at different types of schools, Turkish students satisfy this criterion within a term and at one type of school. Additionally, it appears that legal aspects and health and safety issues related to the teaching profession are included in the Polish ELTEP, but not in the Turkish ELTEP.

The above review shows that the ELTEP in Turkey has received considerable attention from researchers, and the stakeholders of the teacher education positively regarded it and its components in general albeit some criticisms about some aspects of the program. What stood out in the above review is the abundance of studies grounded in the views of teacher educators, student-teachers as well as practising teachers, with more or less similar findings and the scarcity of comparative studies 
that analysed the ELTEPs from several points of views. Therefore, comparative studies seem to have the makings of reaching different yet informative findings that can inform the policy-makers about program's positive and negative aspects, which can be rather practical in the process of program revision.

\section{Research Design and Setting}

\section{Methodology}

This research adopts a comparative qualitative case study methodology in which the researchers are interested in exploring the context and features of two or more cases of particular phenomena at length. The particular phenomena in this research are the two ELTEPs implemented in a Turkish and a Malaysian university. For purposes of comparison, two public universities were chosen from these two countries: the University of Selangor from Malaysia and the University of Burdur Mehmet Akif Ersoy from Turkey. These universities are both state-funded and established institutions in their countries.

\section{Data Collection and Analysis}

To source data from the two universities, a document analysis method was used. We chose this method, especially because "document analysis is particularly applicable to qualitative case studies" and useful for "producing rich descriptions of a single phenomenon, event, organisation, or program" (Bowen, 2009, p. 29). In our analysis, we targeted at electronic (Internet transmitted) materials from the relevant pages of the university websites. Our major objective in using a document analysis method was to "uncover meaning, develop understanding, and discover insights relevant to the research problem", i.e. the convergences and divergences between the ELTEPS in Turkey and Malaysia (Merriam, 1988, p. 118).

For the analysis of the obtained data, bearing in mind the scholars' suggestions (e.g., Labuschagne, 2003; Verma \& Mallick, 1999), content analysis was used to analyse the documentary data to organize the data into examples related to the central issues of the research. The analytical process consisted of the following steps: (1) the relevant webpages of the university websites (i.e. the webpages of the ELT departments) were visited, (2) a first-pass document review was done on the course content by years of education and (3) meaningful and relevant passages of the textual data and other data (e.g., course credits) were identified to be included in the analysis.

\section{Findings and Discussion}

For purposes of clarity, we will first look at the process of language teacher education in the countries in general and then in the two selected universities in particular.

\section{English Language Teacher Education in Turkey}

English language teacher education is provided by ELT (English Language Teaching) programs or FLE (Foreign Language Education) programs of education faculties. To be placed in these departments, it is necessary for students to achieve the required scores from the central university entrance exam. Currently, there are around sixty ELT/FLE programs in Turkey. Graduates of these programs can work as teachers in public schools if they are successful both in the (KPSS) Civil Servant Selection Exam 
and in the oral exam. Although other English language-related programs, such as English Language and Literature, English Translation, American Culture and Literature and English Linguistic programs do not provide pedagogical courses to their students, their graduates can work as language teachers in public or private schools if they obtain a pedagogical formation certificate by attending a teachertraining certificate program (İnceçay, 2011; Karakaş, 2012).

The Council of Higher Education (CHE) is responsible for the content and standard of the programs; however, materials, examinations, course books, and elective courses are determined by the administration of the departments. ELT/FLE programs typically take four years to complete; however, some of the universities require extra intensive preparatory English courses for two semesters. There are compulsory educational, professional and pedagogical courses as well as some elective courses. All public universities are free of charge and private universities can offer scholarships to successful students. Teacher educators hold master's or doctoral degrees.

English teacher education at Burdur Mehmet Akif Ersoy University (MAKU). All information regarding the program has been collected from the official website of the university (MAKU) ${ }^{1}$. The FLE program in the Faculty of Education trains English pre-service teachers. All students need to have the required scores from the university entrance exam. It is a four-year (eight semesters) program and grants a bachelor's degree upon successful completion. All students are supposed to take compulsory courses consisting of educational, professional, and noncompulsory or elective courses.

In the first year, student-teachers take required courses designed to equip them largely with linguistic competence. Additionally, there are educational courses, technology-related courses and courses on their first language, i.e. Turkish. In each term, students have to take 60 -credit courses in total. Course details related to the first year are given in the table below.

In the second year, courses are mostly theoretical and related to subject knowledge in their discipline. As with the first year, they have to complete 30-credit courses in each semester to successfully transfer from the second into the third year. Besides subject-specific courses, they get pedagogical and technology-driven courses intended to improve their teaching skills in congruent with the technological advancements. Finally, as can be seen in the following table, student-teachers get familiar with the target culture by means of courses on English literature and gain insights into the details, nuances and secrets of the first and target languages via translation courses.

\footnotetext{
${ }^{1}$ https://egitim.mehmetakif.edu.tr/fle/about_us.html (English) and https://egitim.mehmetakif.edu.tr/?page=bolumlerYde (Turkish)
} 
Table 1

Courses Offered in the First Year of the FLE Program at MAKU

\begin{tabular}{|c|c|c|c|}
\hline \multicolumn{4}{|l|}{$1^{\text {st }}$ Year (Fall Semester) } \\
\hline Course Title & Type of Course & N.C.* & $\overline{\text { ECTS }}$ \\
\hline Effective Communication Skills & Required & 3 & $\overline{4}$ \\
\hline Advanced Reading and Writing (I) & Required & 3 & 5 \\
\hline Computer (I) & Required & 3 & 2 \\
\hline Contextual Grammar (I) & Required & 3 & 4 \\
\hline Listening and Pronunciation (I) & Required & 3 & 4 \\
\hline Introduction to Educational Sciences & Required & 3 & 4 \\
\hline Oral Communication Skills (I) & Required & 3 & 4 \\
\hline \multirow[t]{2}{*}{ Turkish - I (Written Expression) } & Required & 3 & 3 \\
\hline & Total & 24 & 30 \\
\hline \multicolumn{4}{|l|}{$1^{\text {st }}$ Year (Spring Semester) } \\
\hline Listening and Pronunciation (II) & Required & 3 & 4 \\
\hline Educational Psychology & Required & 3 & 4 \\
\hline Contextual Grammar (II) & Required & 3 & 4 \\
\hline Oral Communication Skills (II) & Required & 3 & 4 \\
\hline Lexical Competence & Required & 3 & 4 \\
\hline Advanced Reading and Writing (II) & Required & 3 & 5 \\
\hline Turkish (II) (Oral Expression) & Required & 2 & 2 \\
\hline \multirow[t]{3}{*}{ Computer (II) } & Required & 3 & 3 \\
\hline & Total & 23 & 30 \\
\hline & Annual Total : & 47 & 60 \\
\hline
\end{tabular}

Table 2

Courses Offered in the Second Year of the FLE Program at MAKU

\begin{tabular}{|c|c|c|c|}
\hline Course Title & Type of Course & N.C.* & ECTS \\
\hline Instructional Principles and Methods & Required & 3 & 5 \\
\hline Approaches to ELT (I) & Required & 3 & 5 \\
\hline Oral Expression and Public Speaking * & Required & 3 & 3 \\
\hline History of Turkish Education & Required & 2 & 2 \\
\hline English Literature (I) & Required & 3 & 6 \\
\hline Linguistics (I) & Required & 3 & 5 \\
\hline \multirow[t]{2}{*}{ English - Turkish Translation } & Required & 3 & 4 \\
\hline & Total & 20 & 30 \\
\hline \multicolumn{4}{|l|}{$2^{\text {nd }}$ Year (Spring Semester) } \\
\hline English Literature (II) & Required & 3 & 5 \\
\hline Language Acquisition & Required & 3 & 4 \\
\hline Teaching Methodology (I) & Required & 3 & 4 \\
\hline Linguistics (II) & Required & 3 & 5 \\
\hline Scientific Research Methods & Required & 3 & 4 \\
\hline Approaches to ELT (II) & Required & 3 & 5 \\
\hline \multirow[t]{3}{*}{ Instructional Technologies and Materials Design } & Required & 3 & 3 \\
\hline & Total & 21 & 30 \\
\hline & Annual Total : & 41 & 60 \\
\hline
\end{tabular}

Third-graders start to get involved in more hands-on activities, i.e. putting the learned theories into practice through micro-teaching, individual and group 
presentations, owing to the nature of the courses given in the third year (see Table 3). They work on projects that will help them shoulder social responsibility regarding their own discipline by participating in various community service initiatives. Moreover, student-teachers are educated about how to integrate literature into their teaching and how to teach English to young learners in case they might be teaching in a primary school after graduation. Lastly, student-teachers take courses each semester on a second foreign language, and may choose either German or Japanese. As with the courses in the previous years, all courses are required and correspond to 60 credits.

Table 3

Courses Offered in the Third year of the FLE Program at MAKU

\begin{tabular}{|c|c|c|c|}
\hline \multicolumn{4}{|l|}{$3^{\text {rd }}$ Year (Fall Semester) } \\
\hline Course Title & Type of Course & N.C.* & ECTS \\
\hline Classroom Management & Required & 3 & 3 \\
\hline Drama & Required & 3 & 3 \\
\hline Second Foreign Language (I) * & Required & 2 & 3 \\
\hline Teaching Language Skills (I) & Required & 3 & 5 \\
\hline Literature and Language Teaching (I) * & Required & 3 & 5 \\
\hline Teaching English to Young Learners (I) & Required & 3 & 6 \\
\hline \multirow[t]{2}{*}{ Teaching Methodology (II) } & Required & 3 & 5 \\
\hline & Total & 20 & 30 \\
\hline \multicolumn{4}{|l|}{$3^{\text {rd }}$ Year (Spring Semester) } \\
\hline Measurement and Evaluation & Required & 3 & 5 \\
\hline Teaching Language Skills (II) & Required & 3 & 5 \\
\hline Services to the Society & Required & 2 & 2 \\
\hline Teaching English to Young Learners (II) & Required & 3 & 6 \\
\hline Literature and Language Teaching (II) * & Required & 3 & 5 \\
\hline Turkish-English Translation & Required & 3 & 5 \\
\hline \multirow[t]{3}{*}{ Second Foreign Language (II) * } & Required & 2 & 2 \\
\hline & Total & 19 & 30 \\
\hline & Annual Total : & 39 & 60 \\
\hline
\end{tabular}

The final year of the program contains, unlike the previous years, a practical side with two courses offered separately in each semester. School experience (observation) and teaching practice (field experience) are required for all studentteachers. They spend two semesters at a particular school. The level of school is determined by the department's faculty staff. In the first semester, student-teachers observe actual classroom teachers, and in the second semester, they have to practice teaching under the supervision of an experienced teacher. This period helps studentteachers to experience a real life teaching environment. Apart from this, studentteachers need to pursue some courses designed to contribute to their contextual knowledge. It is in this final year that student-teachers embark on taking a total number of four elective courses. It is apparent from the course catalogue that the electives are developed for improving student-teachers' linguistic competence. 
Table 4

Courses Offered in the Fourth Year of the FLE Program at MAKU

\begin{tabular}{|c|c|c|c|}
\hline Course Title & Type of Course & N.C. ${ }^{*}$ & ECTS \\
\hline Guidance & Required & 3 & 5 \\
\hline Second Foreign Language III & Required & 2 & 2 \\
\hline School Experience & Required & 3 & 6 \\
\hline Foreign Language Teaching Materials and Development & Required & 3 & 6 \\
\hline Atatürk Principles and Revolution History I & Required & 2 & 2 \\
\hline Special Education & Elective & 2 & 5 \\
\hline \multirow[t]{2}{*}{ Elective I: Asking Questions and Error Correction } & Elective & 2 & 4 \\
\hline & Total & 17 & 30 \\
\hline \multicolumn{4}{|l|}{$4^{\text {th }}$ Year (Spring Semester) } \\
\hline Atatürk Principles and Revolution History II & Required & 2 & 2 \\
\hline Teaching Practice & Required & 5 & 6 \\
\hline Foreign Language Testing and Evaluation & Required & 3 & 6 \\
\hline Comparative Education & Required & 2 & 3 \\
\hline Turkish Education System and School Management & Required & 2 & 3 \\
\hline Elective II: Phonetics & Elective & 2 & 5 \\
\hline \multirow[t]{3}{*}{ Elective III: Advanced Grammar } & Elective & 2 & 5 \\
\hline & Total & 18 & 30 \\
\hline & Annual Total : & 35 & 60 \\
\hline
\end{tabular}

Overall, the descriptive analysis above show that the requirement for a bachelor's degree is to complete 240 credits for the courses and become successful in the practicum. And closer inspection of the tables displaying the given courses in the program indicates that the program is centred around the applied-science model in which student-teachers need to first learn about theories relating to their subject matter and pedagogy, and then exercise this theorised knowledge in actual teaching environments. Moreover, when the tables are closely scrutinised in terms of the distribution of different types of courses on knowledge areas, it is seen that the majority of courses are focused on pedagogical competence (approximately 68\%) whereas the number of courses on linguistic competence is relatively few (around $32 \%)$. What stands out regarding the variety of courses is that courses on field experience (i.e., teaching practicum) is relatively few, making the researchers' criticisms on the lack of opportunities for real-life teaching experiences justifiable (e.g., Erten, 2015; Karakaş, 2012; Kic-Drgas \& Çomoğlu, 2017; Seferoğlu, 2006; ToközGöktepe, 2015). It is also obvious, as earlier stated by Demir (2015), Karakaş (2012) and Sanli (2009), that the number of elective courses is far from being satisfactory in terms of enriching diversity of courses in the program.

\section{English Language Teacher Education in Malaysia}

Colleges and universities provide English language teacher education in Malaysia. Colleges are private foundations and offer three or four years of education. The teachers who graduate from three-year programs can work in primary schools and the teachers who graduate from four-year programs can work at all levels of schools. Every university has its own requirements and it is necessary to individually apply to a desired program. There is no public exam but the high school scores are essential 
for the admission. There are no free universities but scholarships are available for eligible students and loans for others. The TED (Teacher Education Division) is responsible for policies regarding in-service and pre-service teachers. Currently, there are over 60.000 English teachers, and every state has a teacher training college that confers their own certificates (Thirusanku \& Yunus, 2014). There are two types of universities for English teachers. One is the Open University where participants take classes online; the other one is public universities, which conduct both face-toface and online education (Vethamani, 2011). Student-teachers are trained by teacher educators holding either master's or doctoral degrees. The major purpose of teacher education is to enhance student-teachers' social, personal, professional development and increase their inter-cultural awareness (Macalister, 2017).

English teacher education program at the University of Selangor (UNISEL). All the information about UNISEL ${ }^{2}$ is derived from the official website of the university. Teaching English as a Second Language (TESL) is the common name for English teacher education programs. The Faculty of Education \& Social Sciences Department in UNISEL is in charge of providing the TESL program. It is an Islamic university fully run by the government. All applicants need to submit high school or previous school scores, with good grades (2.00 or above). The TESL is a four-year, in total an eight-semester program, and provides a bachelor degree upon successful completion.

Unlike the FLE program of MAKU, UNISEL does not provide a list of courses per year but instead displays a list that puts the courses into five categories: university compulsory subjects, MQA (Malaysian Qualification Agency) compulsory subjects, education foundation, professional practice and discipline core (see, Table 5 below). As in the FLE program at MAKU, there are educational, professional, discipline-related and elective courses in the UNISEL program. It is necessary for student-teachers to have, at least, 122 credits to graduate as an English language teacher.

Apart from the courses listed above, the TESL program offers a variety of elective courses. The electives largely consist of language-specific courses, particularly devoted to the teaching of particular major skills and sub-skills such as writing, creative writing and reading. The elective courses at students' disposal are illustrated in the following table.

\footnotetext{
2 The program can be accessed via the following link: http://fess.unisel.edu.my/v4/3-course-bac-tesl.php
} 
Table 5

Compulsory Courses Offered in the TESL Program (BA) at UNISEL

\begin{tabular}{|c|c|}
\hline Type of courses & Course title \\
\hline UNIVERSITY & Technical English 1 \\
\hline COMPULSORY & Technical English 2 \\
\hline \multirow[t]{4}{*}{ SUBJECT } & Japanese 1 \\
\hline & Mandarin 1 \\
\hline & Arabic 1 \\
\hline & French 1 \\
\hline MQA COMPULSORY & Hubungan Etnik \\
\hline \multirow[t]{8}{*}{ SUBJECT } & Tamadun Islam dan Tamadun Asia \\
\hline & Bahasa Melayu Komunikasi 2 \\
\hline & Pengajian Malaysia 3 \\
\hline & Social Work Skills \\
\hline & Pengajian Al-Quran 2 \\
\hline & Dakwah Islam di Malaysia \\
\hline & Introduction to Malaysian Legal System \\
\hline & Comparative Religion in Malaysia \\
\hline EDUCATION & Philosophy and Development in Malaysian Education Industry \\
\hline \multirow{8}{*}{ FOUNDATION } & History of Education \\
\hline & Global, Comparative and International Education \\
\hline & Educational Psychology \\
\hline & Educational Sociology \\
\hline & Educational Administration \\
\hline & Computer and Technology in Education \\
\hline & Teaching Techniques and Education Management \\
\hline & Educational Research Methodology \\
\hline PROFESSIONAL & Teaching Practicum \\
\hline PRACTICE & Term Paper / Research Project \\
\hline DISCIPLINE CORE & Introduction to General Linguistics \\
\hline (SCHOOL SUBJECT & Introduction to Sociolinguistics \\
\hline \multirow[t]{11}{*}{ CONTENT) } & Introduction to Psycholinguistics \\
\hline & English Grammar \\
\hline & TESL Methodology \\
\hline & Principles of Second Language Learning and Teaching \\
\hline & English Syntax and Morphology \\
\hline & English Phonetics and Phonology \\
\hline & Teaching of English Grammar \\
\hline & Teaching of Writing Skills \\
\hline & Teaching Literature in ESL \\
\hline & Teaching of English for Specific Purposes \\
\hline & Teaching of Aural-Oral Skills \\
\hline
\end{tabular}

As the university website does not provide much information regarding the program and course-related issues, we got some useful information about the program from our intermediaries based in Selangor. As we got informed by one of our intermediaries studying at the TESL department, general compulsory courses are requisite for all students of the universities in Malaysia. MQA compulsory courses are determined by a national committee and delivered by professional teachers. All MQA compulsory courses need to be accredited by this committee first. 
Table 6

Elective Courses Offered in the TESL Program (BA) at UNISEL

\begin{tabular}{|c|c|}
\hline & $\begin{array}{l}\text { Teaching of Reading Skills } \\
\text { ESL Testing and Evaluation }\end{array}$ \\
\hline $\begin{array}{l}\text { ELECTIVE (RELATED } \\
\text { TO DISCIPLINE } \\
\text { CORE) }\end{array}$ & $\begin{array}{l}\text { Material Selection and Adaptation } \\
\text { Academic Writing Skills } \\
\text { Speech and Communication } \\
\text { A Survey of Prose Forms and Poetry } \\
\text { Reading for Academic Purposes }\end{array}$ \\
\hline ELECTIVE (OPEN) & $\begin{array}{l}\text { Creative Writing Skills } \\
\text { Malaysian Literature } \\
\text { Remedial Language Teaching } \\
\text { Literacy Appreciation }\end{array}$ \\
\hline
\end{tabular}

All students are required to have teaching practicum in the last semester of their education. The students can apply either from the website or personally search for any appropriate practicum vacancies. To apply for the practicum, students need to have an updated résumé and fill in the practicum forms with their chosen company or work place. The forms are provided by the university and must be sent to the desired company with the résumé and a cover letter. They can do their practicum in English-speaking non-government organizations, immigration sectors, embassies and public or private schools. During the practicum, they observe, record and teach classes. It is required for all the TESL students to write and present a research project to be able to graduate from the program.

The Malaysian Ministry of Education requires every university student to be successful in MUET (Malaysian University English Test), including student-teachers of English. The MUET system uses a Band-based system in presenting the results. Band 1 is, for example, the lowest and Band 6 is the highest grade. All students need to take this exam and must achieve, at least, Band 3 to complete the program; however, the cut-off score may vary from one university to other. Some of the universities require only Band 2. It is obligatory to get at least Band 3 for TESL students, though.

From the list of courses offered in the program, we can see that the targeted knowledge areas are predominantly about pedagogical competence (e.g., classroom pedagogical skills) and linguistic competence (e.g., the teaching of major skills, increasing their knowledge on (applied) linguistics and its sub-branches, enhancing students' command of English in oral and written communication) as well as contextual knowledge about the education system of Malaysia.

Similarities and differences between the ELTEPS at MAKU and UNISEL. When we compare the programs in terms of course types, we see that the Malaysian ELTEP offer more general compulsory courses than the Turkish ELTEP. While taking a second foreign language, often a European language, is limited to two languages at MAKU, UNISEL requires student-teachers to learn technical English and four additional foreign languages, including European, Asian and Middle-eastern languages. Among the general compulsory courses, the Malaysian ELTEP gives more space to context-dependent, culture-specific and first language-related courses 
compared to the Turkish ELTEP. Based on this, we can conclude that socio-cultural and religious influences are apparent in the Malaysian curriculum.

With respect to the educational courses in both programs, there is almost a balanced distribution regarding the number of courses although course contents and titles differ from each other to some extent. What is intriguing is that the Malaysian ELTEP appears more globally oriented than the Turkish ELTEP, and offers courses integrating technology and computer for pedagogical purposes. Such courses do not stand in the Turkish ELTEP, though. There are also several common pedagogical courses between the two ELTEPs, such as educational psychology, education management, and educational administration.

As for the disciplinary courses, the Turkish ELTEP provides more courses on language, including sub-branches of linguistics such as phonology, lexicology, morphology, and on teaching skills as well as literature and language teaching in comparison to the Malaysian ELTEP. Additionally, the Turkish ELTEP has translation courses whereas the Malaysian ELTEP does not. However, the Malaysian ELTEP offers EAP/ESP courses to help students improve their skills for academic or vocational studies. Referring back to the criticisms about the Turkish ELTEP in terms of its failure to contribute to student-teachers' linguistic competence, it is evident that the Turkish ELTEP contains a good number of courses that can enable studentteachers to achieve linguistic competence. In contrast to earlier findings about the contribution of the program to the development of student-teachers' linguistic competence (e.g., Coşkun-Daloğlu, 2010; Karakaş, 2012; Toköz-Göktepe, 2015), this current comparison provides evidence for the Turkish program's possible potency in equipping student-teachers with the required linguistic knowledge.

Finally, the comparison of the elective courses in the Turkish and the Malaysian ELTEPs illustrates that electives are generally oriented towards increasing student-teachers' disciplinary knowledge, i.e. linguistic knowledge; however, the Malaysian ELTEP is richer in terms of the variety and number of courses students can choose.

When the curricula of each ELTEP has been inspected, it becomes clear that the curriculum of the Turkish ELTEP is more secular than the Malaysian one and there are a few culture-specific courses, which lends support to the criticisms raised about the scarcity of culture-related courses in the Turkish ELTEP (e.g., CosggunOgeyik, 2009; Karakaş, 2012). Nevertheless, courses like Atatürk Principles and Revolution History 1 and Atatürk Principles and Revolution History 2 might be useful for student-teachers who are going to be role models for the youngsters of the country. In contrast, the Malaysian curriculum includes several courses on religion, the Malay language and culture, showing the impact of socio-cultural and religious dimensions on the curriculum.

Similarities and differences between the Turkish and the Malaysian ELTEPs with respect to the length of education, the school types graduates can work at, the total number of credits needed for graduation, career prospects, practicum length, and appointment conditions are summarised in the following table. 
Table 7

Non-course-related Differences Between the ELTEPs in Turkey and Malaysia

\begin{tabular}{|c|c|c|}
\hline Points of comparison & Malaysia & Turkey \\
\hline Length of education & $\begin{array}{l}3 \text { years for colleges, } \\
4 \text { years for universities }\end{array}$ & 4 years \\
\hline $\begin{array}{l}\text { Type of schools that graduates } \\
\text { can teach English }\end{array}$ & $\begin{array}{l}\text { Graduates of colleges; primary } \\
\text { and secondary schools } \\
\text { Graduates of universities; all } \\
\text { types of schools }\end{array}$ & $\begin{array}{l}\text { All types of schools - primary, } \\
\text { secondary and high schools. }\end{array}$ \\
\hline Required credit for graduation & 122 credit & 240 credit \\
\hline Overseas experience & $\begin{array}{l}\text { Transnational program - } \\
\text { spending time in an English } \\
\text { speaking country }\end{array}$ & $\begin{array}{l}\text { Erasmus student-exchange } \\
\text { programs, mostly non-English } \\
\text { speaking European countries }\end{array}$ \\
\hline Career prospects & $\begin{array}{l}\text { Graduates can work as teachers } \\
\text { in government or private schools, } \\
\text { journalists, public relations } \\
\text { officers, human resource officers } \\
\text { or suitable positions in public or } \\
\text { private sectors. }\end{array}$ & $\begin{array}{l}\text { Graduates can work as English } \\
\text { teachers in public or private } \\
\text { schools, translators, tourist } \\
\text { guides, civil servants or any } \\
\text { job that requires a bachelor's } \\
\text { degree. }\end{array}$ \\
\hline Practicum length & 1 semester & 2 semesters \\
\hline Appointment for a job & $\begin{array}{l}\text { Personal application for public or } \\
\text { private jobs }\end{array}$ & $\begin{array}{l}\text { Taking Civil Servant Selection } \\
\text { Exam is necessary for } \\
\text { government jobs. }\end{array}$ \\
\hline $\begin{array}{l}\text { The model of teacher } \\
\text { education }\end{array}$ & The applied science model & The applied science model \\
\hline
\end{tabular}

When we consider the strong aspects of each program, the TESL in Malaysia is provided by both private colleges and universities. However, in Turkey ELT is provided only by universities as a four-year program. In Malaysia, three-year colleges might be beneficial for students who do not want to spend one more year in education and who want to work in primary schools or in jobs, which require college degrees. In Turkey, student-teachers have to complete more credits than their Malaysian counterparts to complete their studies. When we look at the total number of course credits, the Turkish ELTEP almost doubles the Malaysian ELTEP.

In Malaysia the trans-national program offers many opportunities to studentteachers. One instance is that student-teachers can spend some time abroad to improve their linguistic skills. This program employs native English speaking academics, which is an advantage for student-teachers in terms of increased exposure to English. In Turkey, only a small number of students can spend one semester in a European country under the scheme of an exchange program called Erasmus. It has certain requirements and the number of supported students is fairly low due to the budget issues.

As for career prospects, in both ELTEPs, the graduates have diverse options before them. For example, in Turkey, they can work as English language teachers at state-owned schools of all levels of education (primary, secondary, high schools) upon successfully passing the placement exam and at private schools upon successfully fulfilling their job criteria. Besides working as English language teachers, they can also work in the following sectors: business, tourism, translation, and 
language courses, among many others. Likewise, the student-teachers at UNISEL can work as teachers at the primary level of education institutions (e.g., kindergarten and primary schools). In addition, they can be an editor, interpreter/translator, journalist/broadcaster, or customer service representative. For job applications, unlike Turkey, the graduates in Malaysia have to apply for vacant positions in person without having to take a centralized exam.

Concerning field experience (teaching practicum), the ELTEP in Malaysia appears weaker than the Turkish ELTEP since Malaysian student-teachers have practicum only in the last semester of their education. First, they get all the necessary theoretical courses and are then expected to put their theoretical knowledge into practice in classrooms, as a result of adopting the applied science model of teacher education. The length of the practicum differs from one university to another; however, it is usually between fourteen weeks and twenty weeks. It is evident that this limited time may not be enough for student-teachers to get ready for the professional life. We can argue here that theoretical courses and practicums should be well-adjusted so that student-teachers can internalize all the subjects in theory and get more experience in the field in line with their theoretical knowledge.

In contrast, in Turkey, ELT students have their practicums in their last year over two semesters. During the first semester, they only observe the experienced teachers, and in the second semester, they are involved in actual teaching under the supervision of their mentors. The length of the practicum, including the observation phase, is in total 28 weeks and thus longer than the Malaysian one. This difference between the two ELTEPs gives evidence that although researchers (e.g., Demir, 2015; Erten, 2015; İnal \& Büyükyavuz, 2013; Karakaş, 2012; Tok-Göktepe, 2015; Türken, 2017) raise concerns about the deficiency of practicum in the Turkish ELTEP, when compared to those of other countries, it seems that the Turkish ELTEP is, in reality, not as inadequate as it was reported in the previous studies.

\section{Conclusion and Suggestions}

This paper set out to compare the current Turkish ELTEP with that of Malaysia to find out the differences and similarities between the programs and then learn lessons from the strong sides of each program. The comparison of the two ELTEPs revealed that each program has weaknesses and strengths, having superiority over each other with reference to different aspects of the program. To mention the main ones, the Malaysian ELTEP offers more compulsory courses yet fewer language-related courses compared to the Turkish ELTEP at MAKU; there are more elective courses at student-teachers' disposal in the Malaysian ELTEP but fewer opportunities for field experience. Above all these, the Malaysian ELTEP contains religious courses in its curricula while The Turkish ELTEP is quite secular despite Turkey's being a Muslim country like Malaysia. However, this difference in the programs springs from the fact that Malaysia, being described as an Islamic country, follows the doctrine that religion should be integrated into all spheres of life, including political, administrative and educational affairs whereas Turkey, not being identified with a particular religion constitutionally, separates religion directly from its political, administrative, and educational affairs. 
A number of suggestions can be drawn out of our analysis of the two programs. To start with, practicums are placed in the last year of the programs and the allocated time is restricted to several weeks. Perhaps, practicum should be extended to the first year of the program in order to amalgamate theory and practice from the onset of the programs. Student-teachers need to practice at school environment and observe real life environment and have skills that can bridge their theoretical knowledge and practical experiences.

Furthermore, since English enjoys the status of being a lingua franca, program makers might consider designing courses on teaching regional and international dialects of English to make student-teachers raise their awareness about different varieties and uses of English. The lack of such courses is a serious gap in each program and has not been mentioned in previous studies when talking of the weak sides of the Turkish ELTEP.

This research shows that the studies conducted from an insider perspective can produce results that conflict with the results of studies (like the current study), carried out from an outsider perspective, with a comparative focus on ELTEPs in other contexts. It is mainly because what is perceived as a weakness from an insider perspective can actually be a strength when compared to another ELTEP applied in different countries. Therefore, while extrapolating the findings of ELTEP evaluation research, there must be some degree of caution.

In closing the paper, it should be also noted that the paper suffers from some limitations of different types. For instance, a methodological limitation of this study is that since it adopts a qualitative approach with an invested interest in a particular case, the issue of generalization might seem a matter of question. However, there is also the fact that much of qualitative research does not aim to generalize but rather to provide an in-depth contextualized understanding of a particular phenomenon. Therefore, even if researchers from other contexts cannot directly extrapolate the findings and implications of this study to their own situation, the results certainly have some resonance or transferability (Richards, 2003) for other contexts which can further enable other researchers to "share in the researcher's understandings and find instantiations of them in their own professional experience" (Richards, 2003, p. 206).

Moreover, being limited to a comparative document analysis, this study lacks the stakeholders' perspectives on the programs. Had the stakeholders' perspectives been included in the research to complement or supplement the document analysis, the findings might have been different or enriched. An additional uncontrolled factor is the possibility of changes and updates in the programs by program writers. Therefore, the findings are limited to the current programs in use only. When these programs are amended or modified, the findings may be at odds with the renewed programs.

Having identified these limitations, we suggest that further work be done to address these limitations. We also believe that the dual and multi-comparison of the Turkish ELTEP with ELTEPs of different countries, particularly those who are excelled at language teacher education, can yield valuable results, which can then be taken into account by the program writers when revising the program. 


\section{References}

Altan, M. Z. (2006). Preparation of foreign language teachers in Turkey: A challenge for the 21st century. Dil Dergisi, 134, 49-54.

Altunya, N. (2006), Gazi Egitim Enstitüsü - Gazi Orta Ögretmen Okulu ve Egitim Enstitüsü (1926 - 1980), Gazi Üniversitesi 80. Y1l Armaganı, Ankara.

Aydoğan, İ. \& Çilsal, Z. (2007). Yabancı dil öğretmenlerinin yetiştirilme süreci (Türkiye ve Diğer Ülkeler). Sosyal Bilimler Enstitüsü Dergisi, 22, 179-197.

Bowen, G. A. (2009). Document analysis as a qualitative research method. Qualitative Research Journal, 9(2), 27-40. https:/ / doi.org/10.3316/QRJ0902027

Cosgun-Ogeyik, M. (2009). Evaluation of English language teaching education curriculum by student teachers. Insan ve Toplum, 9(1), 42-57.

Coşkun, A. \& Daloğlu, A. (2010). Evaluating an English language teacher education program through Peacock's Model, Australian Journal of Teacher Education, 35(6), 24-42. https:// doi.org/10.14221/ajte.2010v35n6.2

Coşkun, H. (2008). Türkiye ve Almanya' da yabancı dil öğretmeni yetiştirme programlarının karşılaştırılması. C.Ü. Sosyal Bilimler Dergisi, 33(1), 61-73.

Cross, D. (1995). Language teacher preparation in developing countries: Structuring pre- service teacher training programmes, English Teaching Forum, 33(4), 35.

Day, R.R. (1991). Models and the knowledge base of second language teacher education. University of Hawaii Working Papers in ESL, 11(2), 1-13.

Demir, Y. (2015) All or Nothing: English as a Foreign Language (EFL) student teachers' and teacher trainers' reflections on a Pre-service English teacher education program in Turkey, The Anthropologist, 19(1), 157-165. doi: 10.1080/09720073.2015.11891650

Erozan, F. (2005). Evaluating the language improvement courses in the undergraduate ELT curriculum at Eastern Mediterranean University: A case study (Unpublished doctoral dissertation). Middle East Technical University, Ankara.

Erten, I. H. (2015). Listening to practising teachers: Implications for teacher training programs. Procedia - Social and Behavioral Sciences, 199, 581 - 588. https:// doi.org/10.1016/j.sbspro.2015.07.553

Gebhard, J. (2009). The Practicum. In A. Burns \& J. Richards (eds). Second language teacher education, (pp. 250-258). Cambridge: CUP.

Glenfell, M., Kelly, M.Jones, D. (2003). The European language teacher: Recent trends and future developments in teacher education. Oxford: Peter Lang.

Hismanoğlu, S. (2012). İngilizce öğretmeni adaylarının İngilizce öğretmeni yetiştirme programı ile ilgili görüşleri. Ĕ̆itim ve Öğretim Araştırmaları Dergisi, 1(2), 330341.

İnal, S. \& Büyükyavuz, O. (2013). English trainee's opinions on professional development and pre-service education. H. U. Journal of Education, 28(2), 221233.

İnceçay, G. (2011). A critical overview of language teacher education in Turkish education system: From 2nd constitutional period onwards (1908-2010).

Procedia - Social and Behavioral Sciences, 15, 186-190. https:// doi.org/10.1016/j.sbspro.2011.03.071

Karakaş, A. (2012). Evaluation of the English language teacher education program in Turkey. ELT Weekly, 4(15). 1-16. 
Kic-Drgas, J. \& Çomoğlu, İ. (2017). A comparison of English language teacher education programs in Poland and Turkey. Western Anatolia Journal of Educational Sciences, 8(2), 112-121.

Kildan, A.O., Ibret, B.U., Pektas, M., Aydinozu, D., Incikabi, L., Recepoglu, E. (2013). Evaluating views of teacher trainees on teacher training process in Turkey. Australian Journal of Teacher Education, 38(2), 51- 68. https:// doi.org/10.14221/ajte.2013v38n2.10

Labuschagne, A. (2003). Qualitative research - Airy fairy or fundamental? The Qualitative Report, 8(1), 100-103.

Macalister, J. (2017). English and language teacher education in Malaysia: An exploration of the influences on and experiences of pre-service teachers. RELC Journal, 48(1). 53 - 66. https://doi.org/10.1177/0033688217690936

Merriam, S. B. (1988). Case study research in education: A qualitative approach. San Francisco: Jossey-Bass.

Peyton, J.K. (1997). Professional Development of Foreign Language Teachers, ERICNo: ED414768. Retrieved from http:/ / www.cal.org/resources/digest/peyton02.html

Richards, K. (2003). Qualitative inquiry in TESOL. Basingstoke: Palgrave Macmillan. https:/ / doi.org/10.1057/9780230505056

Salihoglu, U. (2012) Pre-service teachers' and their instructors' beliefs on the effectiveness of an English language teacher education program. ProcediaSocial and Behavioral Sciences, 46, 3440-3444. https:// doi.org/10.1016/j.sbspro.2012.06.081

Sanli, S. (2009). Comparison of the English language teaching (ELT) departments' coursecurricula in Turkey's education faculties. World Conference on Educational Sciences. Procedia Social and Behavioral Sciences, 1, 838-843. https:// doi.org/10.1016/j.sbspro.2009.01.150

Seferoglu, G. (2006). Teacher candidates' reflections on some components of a preservice English teacher education programme in Turkey. Journal of Education for Teaching: International Research and Pedagogy, 32(4), 369-378. https:/ / doi.org/10.1080/02607470600981953

Shulman, L. S. (1987). Knowledge and teaching: Foundations of the new reform. Harvard Educational Review, 57(1), 1-23. https:/ / doi.org/10.17763/haer.57.1.j463w79r56455411

Teacher Education - UNESCO UIS. (2018). Teacher education definition. Retrieved from http:/ / uis.unesco.org/node/335181.

Thirusanku, J. \& Yunus, M. M. (2014). Status of English in Malaysia. Asian Social Science, 10(14) 254-260 doi:10.5539/ass.v10n14p254. https://doi.org/10.5539/ass.v10n14p254

Toköz-Göktepe, F. (2015). A critical analysis of foreign language teacher education practices in Turkey. International Journal of Languages' Education and Teaching, 3(1), 128-143.

Türken, M. (2017). A comparative evaluation of the latest ELTTP in Turkey: The lecturers' perspective versus teacher trainees' perspective. Journal of Foreign Language Education and Technology, 2(2), 76-98. 
Ulum, Ö. G. (2015). History of EFL teacher education programs in Turkey. Journal of Research in Humanities and Social Science 3(7), 42-45

Ur, P. (1992). Teacher learning. ELT Journal, 46, 56-61. https:// doi.org/10.1093/elt/46.1.56

Uzun, L. (2016). Evaluation of the latest English language teacher training programme in Turkey: Teacher trainees' perspective. Cogent Education, 3(1), 116. https:/ / doi.org/10.1080/2331186X.2016.1147115

Verma, G. K. \& Mallick, K. (1999). Researching education: Perspectives and techniques. London: Palmer Press.

Vethamani, M. E. (2011). Teacher education in Malaysia: Preparing and training of English language teacher educators. The Journal of Asia TEFL,8(4), 85-110

Wallace, M.J. (1991). Training foreign language teachers. Cambridge: Cambridge University Press.

Weir, C. \& Roberts, J. (1994). Evaluation in ELT. Oxford: Blackwell.

Yavuz, A. \& Zehir-Topkaya, E. (2013) Teacher educators' evaluation of the English language teaching program: A Turkish case. Novitas-ROYAL (Research on Youth and Language), 7(1), 64-83.

\section{Authors' Biodata / Yazar Bilgileri}

Ali KARAKAŞ is an applied linguist and educator who earned his doctoral degree in applied linguistics in 2016 from Southampton University, UK. He served as a research assistant at the Department of English Language Teaching, Mehmet Akif Ersoy University, Burdur between 2009 and 2016. Since 2016, he has been employed as an assistant professor at the same department and offers BA and MA courses. His main research interests include global Englishes, English as a lingua franca, language policy and planning, language ideologies and foreign language teacher education.

Ali KARAKAŞ 2016 yılında doktora derecesini İngiltere Southampton Üniversitesi'nden Uygulamalı Dilbilim alanında almış uygulamalı dilbilimci ve öğretmen eğitimcisidir. 2009-2016 yılları arasında Burdur Mehmet Akif Ersoy Üniversitesi'nde İngiliz dili eğitimi anabilim dalında araştırma görevlisi olarak görev yapmıştır. 2016 yılından bu yana aynı bölümde doktor öğretim üyesi olarak çalışmakta ve lisans ve yüksek lisans dersleri vermektedir. Başlıca araştırma alanları arasında Dünya İngilizceleri, ortak dil olarak İngilizce, dil politikası ve planlaması, dil ideolojileri ve yabancı dil öğretmeni eğitimi yer almaktadır.

Ergül YAVUZ graduated from English language teaching department of Süleyman Demirel University, Isparta in 2016. In 2017, she was enrolled at the master's program of the Department of English Language Teaching, Mehmet Akif Ersoy University, Burdur. Her primary research area is linguistics.

Ergül YAVUZ 2016 yılında Isparta Süleyman Demirel Üniversitesi İngilizce Öğretmenliği bölümünden mezun oldu. 2017 yılında Burdur Mehmet Akif Ersoy Üniversitesinde İngiliz dili eğitimi anabilim dalında yüksek lisans programına başladı. Başlıca araştırma alanı dilbilimdir. 